\title{
For a Vygotskian concept of nurse professional identity: reflective essay
}

\author{
Por um conceito vigotskiano da identidade profissional do enfermeiro: ensaio reflexivo \\ Por un concepto vigotskiano de la identidad profesional del enfermero: ensayo reflexivo
}

'Universidade Federal de Alfenas. Alfenas, Minas Gerais, Brazil. "Universidade de São Paulo. Ribeirão Preto, São Paulo, Brazil.

Rogério Silva Lima'

ORCID: 0000-0002-1751-2913

Marlene Fagundes Carvalho Gonçalves" ORCID: 0000-0003-2965-5409

How to cite this article:

Lima RS, Gonçalves MFC. For a Vygotskian concept of nurse professional identity: reflective essay.

Rev Bras Enferm. 2020;73(6):e20190172.

doi: http://dx.doi.org/10.1590/0034-7167-2019-0172

\section{Corresponding author:}

Rogério Silva Lima

E-mail: rogerio.lima@unifal-mg.edu.br

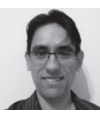

EDITOR IN CHIEF: Antonio José De Almeida Filho ASSOCIATE EDITOR: Mitzy Reichembach

Submission: 03-08-2019

Approval: 10-20-2019

\begin{abstract}
Objective: to understand the nurse professional identity from a vygotskian perspective and to understand its implications in the education process of nursing students. Methods: theoretical-reflexive study, based on the historical-cultural approach of Lev Seminovich Vigotski. Results: the perspective of human cultural development defended by Vigotski can support an understanding of nurse professional identity as a complex psychological construction, which takes into account both the elements of the historical-cultural context that circumscribes the profession and the subject, as well as the set of psychological functions, developed by the subject in personal and professional relationships. Final considerations: the professional identity formation necessarily passes through the social relations that take place in formative process and it places the nursing professor in relief in the conduct of learning, which results not only in appropriations of attributes and codes, but also in students psychological development.

Descriptors: Identities, Social; Nurses; Identification; Nursing Students; Nursing Education
\end{abstract} Research.

\section{RESUMO}

Objetivo: Compreender a identidade profissional do enfermeiro a partir de uma perspectiva vigotskiana e depreender suas implicações no processo de formação dos alunos de enfermagem. Métodos: Estudo teórico-reflexivo, baseado na abordagem histórico-cultural de Lev Seminovich Vigotski. Resultados: A perspectiva de desenvolvimento cultural humano defendida por Vigotski pode alicerçar uma compreensão de identidade profissional do enfermeiro como uma complexa construção psicológica, a qual leva em conta tanto os elementos do solo histórico-cultural que circunscrevem a profissão e o sujeito quanto o conjunto de funções psicológicas, desenvolvido pelo sujeito nas relações pessoais e profissionais. Considerações finais: A formação da identidade profissional passa, necessariamente, pelas relações sociais que se dão no processo formativo e que colocam o professor enfermeiro em relevo na condução da aprendizagem, resultando não apenas nas apropriações de atributos e códigos, mas também no desenvolvimento psicológico dos estudantes.

Descritores: Construção Social da Identidade; Enfermeiras e Enfermeiros; Identificação; Estudantes de Enfermagem; Pesquisa em Educação de Enfermagem.

\section{RESUMEN}

Objetivo: comprender la identidad profesional del enfermero a partir de una perspectiva vigotskiana y comprender sus implicaciones en la formación de los alumnos de enfermería. Métodos: Estudio teórico-reflexivo, basado en el enfoque histórico-cultural de Vigotski. Resultados: la perspectiva de desarrollo cultural humano defendida por Vigotski puede fundamentar una comprensión de identidad profesional del enfermero como una compleja construcción psicológica, que tiene en cuenta tanto los elementos del suelo históricocultural que circunscribe la profesión y el sujeto, como el conjunto de funciones psicológicas, desarrollado por el sujeto en las relaciones personales y profesionales. Consideraciones finales: la formación de la identidad profesional pasa necesariamente por las relaciones sociales en el proceso formativo y que colocan al profesor enfermero en relieve en la conducción del aprendizaje, que resulta no sólo en las apropiaciones de atributos y códigos, sino también en el desarrollo psicológico de los estudiantes

Descriptores: Construcción Social de la Identidad; Enfermeros; Identificación; Estudiantes de Enfermería; Investigación en Educación de Enfermería. 


\section{INTRODUCTION}

In view of the contemporary challenges in the field of health, there has been a pressing need to rethink the education of nurses, not only in relation to the quality of formal education, but also with regard to the need to empower students with the perspective of "being"(1). In this sense, it is also necessary to investigate the processes related to the construction of the identity of nurses, and undergraduate training can be seen as a favorable space for this investigation ${ }^{(2)}$.

The construction of the professional identity of nurses is a complex phenomenon that does not occur automatically in the subjects and that takes into account the social changes and the relationships established throughout their history ${ }^{(3)}$. This way, in order to rethink the paths taken in the development of the professional identity of nurses among undergraduate students and to analyze the strategies and resources that are mobilized for this purpose, it is necessary to find a way to analyze the genesis of the phenomenon, not just its surface or its psychological or social functioning.

This approach aims to look at the phenomenon not as an outcome, but as a continuous process of development, and implies searching for references that allow understanding the dynamic, social and psychological relationship that enables a person to become a nurse.

In this sense, the cultural-historical approach proposed by Vygotsky may favor an analysis that sheds light on the development of the professional identity of nurses, since it starts from the conception that the human being is a historical category. In addition, the process of developing their Higher Mental Functions (HMF) depends on the social relationships that make it possible to take ownership of elements of culture ${ }^{(4)}$, which can, in this analysis, mean those elements that are produced and shared within the scope of a productive activity, such as nursing.

The choice for this framework implies the abdication of idealistic or mechanistic visions, since it is not possible to understand the world and the man as separate entities, as if one did not impose reciprocal modifications to the other ${ }^{(4)}$.

Thus, seeking to contribute to the proposals for advances in higher education training in nursing, this reflection on the professional identity of nurses from a Vygotskian perspective of human development is proposed, with the objective of unveiling the possible implications for the field of teaching.

\section{OBJECTIVE}

This essay aims to understand the professional identity of nurses from a Vygotskian perspective of human development, in order to unveil the possible implications for the field of teaching.

\section{The cultural-historical genesis of the identity of the nurse: implications for the training of new professionals}

We approached the professional identity of nurses in the context of human psychological development. This development is understood in a materialistic and dialectical perspective, as a revolutionary, nonlinear process that goes through qualitative transformations, spiraling to higher levels of mastery of one's own conduct ${ }^{(5)}$.

For their development, human beings assimilate social experiences that take place in a system of abstract concepts, and then, imbued with these new appropriations, transpose the limits of sensory experience that would restrict them to the biological sphere ${ }^{(6)}$. This reflects the cultural development of human beings, which resides in the ability to elaborate signs and artificial stimuli, from which they can guide their conduct and master their own behavior through the development of $\mathrm{HMF}^{(4)}$.

These functions, which include abstract thinking, logical memory and concept formation, stem from the social environment ${ }^{(4)}$. Thus, every psychological and intrapsychic function of the subject is also an interpsychological function, developed in the social environment, and not only biologically inherited. This way, when what was shared between two people is appropriated by the subject, it becomes their patrimony ${ }^{(6)}$.

Auxiliary stimuli called signs take part in this process of appropriation. The social being creates a series of artificial stimuli to master their own or others' conducts. These elements are primarily present in the relationships between men, and then become a tool for men's influence over themselves, enabling them to master their conduct and the conscious use of their potentialities ${ }^{(4)}$.

Therefore, through operations with signs, psychological activity can be restructured and cultural forms of behavior can be appropriated ${ }^{(4)}$.

In this process, human beings must appropriate the ideas, codes and models that explain the reality and that allow them to access and know the world around them. Therefore, the other has the essential role of indicating the signs and their signified ${ }^{(7)}$. The indications given by the other in the social environment establish the reciprocal relationship between sign and signified ${ }^{(4)}$.

Thus, the role of the social environment in the development of the subject and in their participation in the cultural, professional and social world is emphasized ${ }^{(8)}$. The social environment is not static; it changes as men create the conditions of social existence, as well as their own conditions of material existence ${ }^{(7)}$.

The social environment puts the subject in contact with new necessities that provoke the development of specifically human functions ${ }^{(8)}$. In other words, the relationships between subject and environment are modified according to their level of psychological development. This development, in turn, is influenced by the new relationships established by the subject.

Considering this, it is possible to understand the professional identity of nurses as a phenomenon of social and cultural origin. Therefore, the construction of this identity comes from social life, due to the social constitution of human beings. Our historical trajectory led to the emergence of uniquely human needs that, in turn, enabled the development of professional activities, the accumulation of knowledge and the development of attributes and codes related to productive activities.

Life in society allows men to create and develop complex psychological systems that enable work activities and social life itself. Therefore, first and foremost, all that is cultural is social ${ }^{(4)}$. However, if, on the one hand, social life is a condition for the emergence of culture, on the other, it is also the result of culture, given that men's creative action is what engenders different forms of human sociability ${ }^{(7)}$. As a product of social life and of human activity ${ }^{(4)}$, culture includes the totality of human productions, such as technical, artistic and scientific productions, traditions, institutions and social practices. Therefore, culture is, related to the new conditions of existence created by men 
since they discovered their ability to transform the nature of which they are part ${ }^{(7)}$.

Based on this, it is deduced that the professional identity of nurses is related to nursing as a dialectical productive activity. This means that at the same time that it is a result of the conditions of the historical possibilities related to the social sphere, it also determines the conditions of possibility, when its development changes the social and cultural environment.

When conceiving nursing as a profession, we recognize that nursing workers have a necessary social function, based on a set of knowledge produced by the workers and transmitted to those who are in the training process, with standards of professional conduct and ethics guided by their own code of ethics and with their own representative entities ${ }^{(9)}$. These attributes are cultural productions that, of course, are originated in work activities, which, in their historical trajectory, led to the constitution of nursing as it is.

This means that the professional identity of nurses is not a static factor manifested only by the behavior of the subjects in the context of a group, and that it is not represented only by the subjects' perception of their own actions as professionals. It is a complex psychological construct that takes into account the elements of the cultural-historical context of the profession and of the subject, both in motion, and the set of psychological functions developed and operated by the subjects in their personal and professional relationships, as products and producers of new cultural appropriations.

Always in motion, the development of this set of functions is closely related to formal teaching environments, as they provide favorable conditions for the subject to appropriate the cultural productions related to being a nurse. These aspects of the development of the HMF lead to new perspectives on education and new ways to address the educational task ${ }^{(8)}$.

In the cultural-historical approach, the development of the subjects, considering their HMF and conscience, is closely related to the learning process, which precedes development and depends on the cooperation of others. Development due to learning is fundamental in the emergence of typically human properties. Learning leads to the development of the subject and the maturation of their functions for lifetime. The two processes are connected in complex interrelations ${ }^{(8)}$.

In educational spaces the subject finds a favorable environment for the development of conceptual thinking. The scientific concepts taught in school are capable of transforming or enhancing daily life concepts, which are apprehended by experience. Therefore, they provide the subject with the possibility of subordinating their psychological operations to their own power, orienting their activity towards solving the problems around them and operating voluntarily with their own abilities ${ }^{(8)}$.

Through the development of conceptual thinking, human beings can actively and creatively participate in the cultural life presented to them, as well as understand and manage the world around them ${ }^{(8)}$.
Hence the relevance of the educational space in the construction of the professional identity of nurses, considering that it is in this context that students can advance, leaving behind the empirical conceptions about the profession, which come from common sense, and appropriating new knowledge that contribute to other configurations of this labor activity.

This is because the process of attributing new configurations to everyday concepts through the learning of scientific concepts helps individuals to make a qualitative leap in their development, improving and acquiring new psychological functions and mastering new forms of conduct ${ }^{(8)}$.

In this line of thought, teaching activities, whether theoretical or practical, insertion in health services of various kinds, outreach projects and research activities need to be considered, in the context of undergraduate nursing, as opportunities for the development of functions related to the professional identity of the nurse. That is, the operationalization of these components must be intended to provide students with learning opportunities that can lead to the development of their functions, which, in turn, can be expressed in professional behaviors that transform reality.

Education and the professor, in this paradigm, occupy a central aspect in the configuration of men. The educational process emerges as an element of great importance in the construction of the professional identity of the future nurse, as students can appropriate the signs and signified of being a nurse to themselves in order to become nurses as the other has indicated, before they become nurses to themselves, with self-awareness and voluntary mastery of the processes related.

\section{FINAL CONSIDERATIONS}

The Vygotskian theories that underlie the understanding of human development make it possible to understand the professional identity of nurses as a complex psychological construct. To this end, it is necessary to consider the elements of the culturalhistorical context of the profession and of the subject, both in motion, and the set of psychological functions developed by the subjects in their personal and professional relationships, as products and producers of new cultural appropriations.

Assuming that professional identity is this ever-evolving set of functions implies abdicating a teaching conception that is the basis for pedagogical practices of knowledge transmission, as if identity were the result of an equation.

Thus, the construction of identity necessarily goes through the social relations that occur in the training process, highlighting the figure of the nurse professor in the conduction of learning. Thus, teaching must result not only in the appropriation of attributes and codes, but should also support the students' psychological development so that it can transform them - not only reproduce them - during their professional practice.

\section{REFERENCES}

1. Adamy EK, Teixeira E. The quality of education in times of new National Curriculum Parameters. Rev Bras Enferm. 2018;71( Suppl 4):1485-86. doi: 10.1590/0034-7167-201871sup401 
2. Lima RB, Dias MSA, Brito MCC, Silva AV, Silva LMS, Coutinho JFV. Social representations of students in the construction of the professional identity of nurses. Rev RENE. 2018;19:e32468. doi: 10.15253/2175-6783.20181932468

3. Teodósio SS, Padilha MI. "To be a nurse”: a professional choice and the construction of identity processes in the 1970s. Rev Bras Enferm. 2016;69(3):428-34. doi:10.1590/0034-7167.2016690303i

4. Vygotski LS. Obras escogidas III: problemas del desarrollo de la psique. Madrid: Visor Distribuiciones; 2000. 383 p.

5. García LD. El desarrollo psicológico humano como processo de continuidade y ruptura: la "Situacíon social del desarrollo". Educ Filos. 2015;57(suppl 29):21-42. doi: 10.14393/REVEDFIL.issn.0102-6801.v29n57a2015-p21a42

6. Luria AR. Pensamento e linguagem: as últimas conferências de Luria. Porto Alegre: Artes Médicas; 1986. 251 p.

7. Sigardo AP. O social e o cultural na obra de Vigotski. Educ Soc. 2000;21(suppl 71):45-78. doi: 10.1590/S0101-733020000000200003.

8. Vygotski LS. Obras escogidas II: problemas de psicología general. Madrid: A. Machado Libros; 2001. 484 p.

9. Pires D. A enfermagem enquanto disciplina, profissão e trabalho. Rev Bras Enferm. 2009;62(5):739-44. doi: 10.1590/ S0034-71672009000500015 